\title{
A Century of Bibliographic Instruction: The Historical Claim to Professional and Academic Legitimacy
}

This paper links the origin, decline, and renaissance of bibliographic instruction (BI) to the increasing specialization and democratization of education. It argues that BI in academic libraries and the reference desk in public libraries were both initiated to foster independent learning by unsophisticated users; that BI, introduced by scholar-librarians in the 1870s, could not be sustained by the semiclerical graduates of early library schools and was consequently displaced by the reference desk, and that improved training and status for librarians contributed to the BI renaissance of the 1960s. Library schools should recognize the centrality of BI to academic librarianship and develop its theoretical base. Concept-oriented BI can help students understand the disciplines as different but equally rigorous approaches to knowledge by comparing their bibliographic structures and research methods.

\section{INTRODUCTION}

Three broad themes comprise the major bibliographic instruction (BI) issues that are now coming to the fore, and define the likely dimensions of BI's continuing development. Intellectually, BI librarians, or instruction librarians, as they will also be referred to here, are striving to move BI content from facts and procedures to concepts and theory. Socially, they are struggling on two fronts: in the academic environment they seek recognition of the educational value of bibliographic instruction; in their own professional environment, they seek its recognition as a core function of librarianship. These are not new themes, of course. The difference now is that there is finally a critical mass of instruction librarians who are confident and experi-

Frances L. Hopkins is head of the Reference Services Department, Temple University Library, Philadelphia, Pennsylvania. enced in the teaching role and ready to put these basic issues first.

In this paper, these three dimensions will be projected backward into the early history of bibliographic instruction. What were the intellectual and social issues then and how were they related? An approach from this perspective may illuminate the present situation and help BI librarians go forward with a clearer sense of purpose.

\section{HistoRY}

The modern American system of higher education and the development of librarianship as a distinct occupation both had their origins soon after the Civil War, as a consequence of four interdependent social forces: the growing importance of technology, the democratization of American culture, the secularization of knowledge, and the burgeoning of basic scientific research and systematic scholarship. ${ }^{1}$ The character of academic libraries was shaped by their dual 
environment of academia and librarianship, and the early rise and swift decline of bibliographic instruction between 1870 and World War I can be traced to the combined effects of these environments.

Until the 1860s American higher education followed the British model. Through a fixed religious and classical curriculum, the goal was to turn upper-class youths into moral, cultured gentlemen. In 1862, when the Morrill Act provided federal land grants for the establishment of institutions to teach "agriculture and the mechanic arts," higher education was transformed into an instrument for social betterment. In the 1870s the same spirit motivated introduction of the elective system. Both elite, private Harvard and democratic, land-grant Cornell began allowing students to fashion their own programs, opening the way for faculty members to offer whatever courses their interests dictated. For the presidents of both institutions this was a deliberate means of replacing the old curriculum with new, socially useful subjects without first having to debate educational philosophy with conservatives.

The elective system was widely copied, and the resulting proliferation of college subjects led not only to a demand for more professors but to a demand for a new kind of professor-the subject specialist to replace the generalist, who had been master of all subjects in the old, narrow, fixed curriculum. As the transformation of college education progressed, the enlarged, specialized faculties became grouped into academic departments. Their specialized expertise soon brought them the right to determine programs and standards within their own fields, a power formerly centralized in the president. While this decentralization was occurring at the college level, the rapid development of scientific research and systematic scholarship, modeled on the German achievement, led to the establishment of research-oriented graduate education. Johns Hopkins, which opened in 1876 (with, it should be noted, a former Yale librarian, Daniel Gilman, as first president), was planned as a graduate institution only. Harvard, anticipating competition from this new university, was prompted to offer graduate-level courses in 1875.

This educational revolution of the 1870 s was accompanied by a surge of library development. ${ }^{2}$ Both university and public libraries began building research collections in the 1860 s. The technical problems of organizing large collections for efficient access were solved by Dewey's classification scheme, developed at Amherst College in the 1870s, and Cutter's dictionary catalog, which was introduced at Harvard in 1861 . The new research libraries existed for the sake of scholars, and it was reasonable to assume that professors working in specialized fields knew their literature and could cope with classification and cataloging schemes. But the broadening of college course offerings under the elective system and the new independence of students was creating a class of novice library users. Librarians championed students' right to independent access by extending library hours beyond the usual one or two days a week and by helping students select books and find information.

Most of the early academic librarians were professors, responsible part-time for the library, possibly chosen for the job because they retained generalist interests in an era of increasing specialization. Their natural inclination in an academic setting was to teach the use of library materials for academic purposes. Justin Winsor, appointed at Harvard in 1877 as professor of bibliography and one of the few full-time academic librarians, was a Harvard graduate who had studied at Paris and Heidelberg and was a respected historian and cartographer. ${ }^{3} \mathrm{He}$ believed that colleges should "pay more attention to the methods by which a subject is attacked" and should "teach the true use of encyclopedic and bibliographic helps." 4

Azariah Root of Oberlin College Library had an Oberlin BA and an MA, had studied law at Boston University and Harvard, and had spent a year at Göttingen, ${ }^{5}$ whose library provided the standard for the new American universities. ${ }^{6}$ From 1899 to 1927 he taught a sequence of courses on library organization, bibliographic resources, and the history of the book. ${ }^{7}$ Edwin Woodruff, reporting on BI at Cornell in 1886, wrote that it was the "duty of a college library to teach the student how he may, if necessary, at any time in his post-collegiate years, seek out and use the books that have displaced or carried along the knowledge of his college days" and 
to "reveal to [the student] the fact that no professor's word is final." 8

Academic librarians were thus on the way to establishing a position for themselves as educators, and they could perhaps have filled in part the general education role abdicated by a specialized faculty. But the inexorable flood of acquisitions in research libraries caused a shortage of trained librarians, who learned their profession one by one as apprentices after receiving their college degrees. Responding to the shortage, Melvil Dewey opened his School of Library Economy at Columbia in 1877, where he was then librarian. With reformist zeal, he not only admitted women to his school but required only native ability and good character for entrance, over strong protest by Winsor and other leaders in the field. Other library schools followed his lead. Courses in the early library schools were entirely practical, emphasizing typing and "library hand" as well as classification. ${ }^{9}$ Thus, classification and cataloging, which had required enterprising intelligence for their invention, were largely routinized within a few years into semiclerical work.

Most of the new library school graduates were neither the intellectual nor social equals of academic faculty. BI of the sort developed by Winsor and Root could not be routinized or divorced from familiarity with the curriculum and research methods, and it is unlikely that the new breed of librarian would even have attempted it. But the head librarians, although still appointed from the professorial ranks, were also being pushed from the teaching role by collection growth. In larger libraries, at least, they had to function more as administrators than as educators, responding more to the demands of powerful departments than to student needs and presiding over a proletariat of assistant librarians who were little more than clerks. There were, of course, a number of very able women in the field, as a check of Notable American Women will reveal, but there is no doubt that Dewey's good intentions depressed the profession as a whole.

A bibliography of articles on academic library instruction published between 1876 and 1932 documents the decline from instruction in use of library materials for research to instruction in access procedures. ${ }^{10}$
The early entries from such institutions as Harvard, Princeton, Yale, Amherst, Dartmouth, Bowdoin, Wesleyan, Columbia, and Johns Hopkins show the influence of the Winsor-Root-Woodruff approach. From 1907 on, there is increasing incidence of articles on teaching basic access skills to freshmen in normal schools and agricultural colleges, and by 1926 the opinion was published that freshman instruction is remedial and should be the responsibility of the high schools.

Meanwhile, another approach to user assistance was taking hold in academic libraries. In 1876 Samuel Green reported his introduction of formal reference service at the Worcester, Massachusetts, Public Library. ${ }^{11}$ Public libraries had a concern for the needs of unsophisticated users similar to the academic librarians' concern for students, and the idea of having a librarian at a visible desk to give ad hoc responses to individual users' questions was gradually adopted into academic libraries. Unlike BI, reference service required no planning or lecturing, no direct involvement in the academic program, and little exposure to faculty scrutiny. To the average library school graduate, the role of reference librarian must have been much more congenial than any attempt to emulate Justin Winsor as professor of bibliography.

Yet interest in BI at an intellectual level did not disappear. In 1928 the librarian of Swarthmore College criticized the shallowness of the library instruction usually given to freshmen and suggested establishing academic departments of bibliography that could offer sequenced courses in library research. ${ }^{12}$ In 1934 Louis Shores first described his idea of a library-college in which teaching librarians would team with subjectspecialist professors to guide undergraduates in independent, interdisciplinary study. ${ }^{13}$ Harvie Branscomb, in a report commissioned by the Association of American Colleges, made a similar recommendation in $1940 .{ }^{14}$

All of these proposals were tied to the ideal of general education for undergraduates in an era when specialization was ascending. Indeed, increasing specialization of teaching at the undergraduate level was recognized as a mixed blessing almost as soon as the old cur- 
riculum had been overthrown. The elective system suited that minority of undergraduates who had well-defined scientific or vocational interests and who knew what courses they needed to achieve their goals. But less directed students often floundered, and many faculty still believed that character formation through broad humanistic study should be the essence of undergraduate education. Yet repeated attempts from the 1880 s through the 1940s to introduce general education programs in major universities were thwarted by lack of consensus on an essential core of knowledge, by the ambivalence of science faculty, by reward systems that favored faculty research over teaching, and by suspicion of lingering elitism.

After World War II, from 1945 to about 1970 , changes in the production of knowledge and in higher education repeated those that had followed the Civil War. Again, government support brought a sudden expansion of research in science and technology. Exponential growth in the volume of research literature was followed by extensive ramification of the bibliographic apparatus. Academic libraries responded, as they had in the 1860s and $70 \mathrm{~s}$, with rapid collection growth and with new techniques of organization and retrieval. Consequently, in the 1960 s, as in the 1880 s, there was a severe shortage of trained librarians. The library schools had been upgrading gradually and the fifth-year master's degree had by this time become standard; now the schools began offering courses in documentation and computer applications. Job mobility and salaries improved, and librarians began to gain some recognition as technical experts. In academic libraries, directorships formerly held by nonlibrarian scholars were now more often filled by administrators with technical knowledge.

Through the 1950s library instructionusually routine or merely remedial where it was offered at all - was almost completely eclipsed by developments in technical services, which were at once more interesting and more advantageous for the professionalization of librarianship. In 1956, Jesse Shera, one of the chief spokespersons for intellectualism in librarianship, advised librarians not to pursue the teaching role. ${ }^{15} \mathrm{He}$ recommended, instead, that librarianship be devel- oped as a discipline in its own right, comprising subject bibliography, the theory and techniques of documentation, and the investigation of how scholars and students make use of recorded knowledge. He outlined the subject matter of a social science discipline of librarianship that would have been the ideal theoretical base for the Justin Winsor approach of tying practical instruction in research techniques to the "method by which a subject is attacked" by scholars. But Shera apparently saw nothing in this relevant to undergraduate education; he certainly saw no realistic hope that librarians could participate directly in the educational process.

Also after the war, a new wave of government-supported democratization of higher education extended the democratization begun by the land-grant act of the previous century. The ideal of universal higher education brought in a huge student population with a greater range than ever before of academic abilities and preparation. Vocational-professional programs proliferated; teaching in the traditional science and social science fields became more preprofessional as the ever more specialized faculty found more of their students aiming for graduate study. Again, the increasing fragmentation of knowledge into specialties produced a counter-movement, this time strengthened by reaction to the impersonality of mega-universities. In the 1960s rigid syllabi and assigned paper topics gave way to more independent study as faculties accommodated to student rebelliousness. Several small experimental colleges were founded in an effort to provide the option of integrative, humanistic education for more undergraduates.

Just as the decline of BI early in the century had been the product of social forces in the professional and academic environments, so was its revival in the 1960s. Two problems related to developments in education could be tackled only through systematic group instruction, and librarians, equipped now with better training and higher status, were ready for the challenge. The first problem concerned the continuing effects of specialization. Patricia Knapp's grant-funded project at Monteith, one of the new small colleges, reflected her conviction that library competence is a liberal art that is systemati- 
cally ignored by subject specialists intent on imparting content rather than competence in learning. ${ }^{16}$ She developed a problem-solving approach to library instruction.

The second problem was the consequence of rapid democratization combined with the increasing complexity of libraries. In the public colleges and universities especially, ad hoc reference service was not adequate to the needs of increasing numbers of students who lacked basic library competence but who were nevertheless expected to cope with a bibliographic apparatus geared to graduate students and faculty. In this situation, library instruction focused on general access skills and on use of the more technical bibliographic tools. These two strains-problemsolving and access-skills instructionpersisted through the 1970 s, but they seem now to be converging gradually into the concept-oriented instruction that is being developed in the 1980s.

\section{HYPOTHESIS}

The three dimensions of bibliographic instruction will again be examined, this time in a different order. It was stated earlier that "in their own professional environment [instruction librarians] seek recognition of [bibliographic instruction] as a core function of librarianship"; "intellectually, [they] are striving to move [its] content from facts and procedures to concepts and theory"; and "in the academic environment they seek recognition of [its] educational value." How does the historical perspective enable BI librarians to see more clearly where they stand?

Consider first the place of BI in librarianship. Library collections and technology were developed originally for the support of scholarship. But librarians were motivated also by a strong social service ideology. They sought to provide not only access to libraries by the untutored, but also assistance in use, without which access alone would have been for many a pointless privilege. Public librarians appropriately established reference desks. They placed them only in the popular reading areas where questions would not usually arise from the context of academic disciplines, not in reading rooms used by scholars. ${ }^{17}$ Academic librarians, also appropriately, offered instruction to students in the use of library resources to answer questions that normally did arise from academic disciplines.

At one level, the purpose of the public library reference desk and academic library instruction was the same: the democratic goal of fostering independent learning, free from reliance on tradition or authority. But in the academic library the "authority" of the disciplines could not reasonably be ignored. To learn independently in that context, the student had to learn how to keep up with ongoing research and how to evaluate one expert opinion in the light of others. The reference desk was designed for responding to specific questions and providing information, not for imparting such an understanding of general research principles.

Thus, it is hypothesized here that the reference desk, offering ad hoc information service, displaced $\mathrm{BI}$ so decisively as the focus and ideal of academic library service largely because few graduates of the clerically oriented library schools had the competence or status to teach research methods, however tenacious they often were in the search for information. If this theory is correct, the concurrent rise of the reference desk and decline of group instruction in academic libraries was an unintended consequence of Dewey's social conscience, not a deliberate redefinition of the academic librarians' role. Therefore, historically as well as logically, BI librarians are on firm ground in claiming that $\mathrm{BI}$ is one of the primary functions of librarianship and are right in insisting upon its inclusion in library school curriculums.

Second, consider the matter of content. $\mathrm{BI}$, as originally conceived by the professorlibrarians, was intended to teach broad problem-solving research methods. That goal, which lends itself to conceptual approaches, has survived mainly in the small liberal arts colleges that now enroll only a minute proportion of American students. In the public universities that have dominated modern higher education, the combination of huge student populations comparatively lacking in basic academic skills, the increasing complexity of libraries, and the technical character of many academic programs has of necessity focused BI on tools and locational procedures.

But experience has shown that knowledge of technique is not enough. It does not, for 
example, enable students to cope with discrepancies or bias in standard reference works, to distinguish scholarship from journalism, or to judge the kind of resources needed at each juncture in the research process. And learning theory confirms that facts and procedures isolated from a meaningful structure are neither grasped well nor retained. Lately, therefore, the search for theoretical principles, once seen as a luxury for those who could instruct small groups in selective colleges, has taken on a more practical urgency.

So far, BI has been a pragmatic enterprise advanced through informal observation of student researchers, through largely unevaluated efforts to teach them more efficient ways, and through continuing adjustment to institutional realities. Instruction librarians have made painfully slow progress, theoretically, since Patricia Knapp's work in the early 1960s. Now that they agree in general on the need for theory, perhaps they can consciously cultivate appropriate research. Medical education was revolutionized a century ago when American university medical schools accepted the responsibility to pursue whatever research was relevant to professional practice. ${ }^{18} \mathrm{BI}$ librarians should expect no less. They already draw on studies of scientific publication and citation patterns, and they need precise behavioral studies of how scholars in different disciplines and novice researchers use the literature. BI librarians need to make qualified researchers aware of them and of their needs; fruitful cooperation might result.

Finally, consider the educational role of BI. It has been seen how increasing specialization has fragmented the undergraduate curriculum, leaving students vulnerable to the mistaken view that a given discipline is truth. Many faculty members regret in principle the abandonment of general education, yet their own interests are often incompatible with educating the whole student. They are trapped in a system that requires highly specialized research for professional survival. Repeated efforts to overcome the effects of fragmentation by required general courses have all failed, having been accused of cultural insularity, snobbishness toward middle-American materialism, or sheer vacuity. So the need remains for a means to syn- thesize fragmented knowledge without resort to any suspect value system.

It is this author's belief that the growing interest in the philosophy and sociology of knowledge has been at one level an effort to tame the arrogance of disciplines. There is a need to reduce them to human size by understanding them as alternative approaches to knowledge of the world, with no exclusive claim to truth and no immunity to the social forces that influence every other human enterprise. Philosophy and sociology of knowledge, however, are not easily presented to undergraduates; they require too much background in cultural history. But bibliographic instruction may provide a relatively value-free approach to the comparative study of academic fields and disciplines that is accessible to undergraduates. It is possible to use publication and citation patterns to compare what counts as knowledge in the different subject fields and to contrast the processes by which their knowledge is generated, evaluated, and used, or consigned to the archive.

\section{Conclusion}

BI librarians are therefore justified in claiming a central role for bibliographic instruction both within librarianship and within the larger academic enterprise. Their predecessors once saw the teaching of research methods as a basic function of academic libraries; the present generation may see the realization of their vision. This generation of instruction librarians knows more about the structures of disciplines and the ways of learning than did previous generations. And in the increasingly specialized and divided groves of academe, the need for an integrative role for $\mathrm{BI}$ is even greater.

\section{REFERENCES}

1. Joseph Ben-David, American Higher Education: Directions Old and New (New York: McGraw-Hill, 1972), is the source of all historical information on American education.

2. The source for information on the early development of academic libraries is a series of articles on academic libraries in 1876 published in the issues of College \& Research Libraries, V. 37 (1976). They were reprinted in Richard D. Johnson, ed., Libraries for Teaching, Libraries for Research: Essays for a Century, 
ACRL Publications in Librarianship, no.39 (Chicago: American Library Assn., 1977).

3. James Truslow Adams, "Winsor, Justin," Dictionary of American Biography, V.10 (New York: Scribner, 1936), p.403-4.

4. Justin Winsor, "The Development of the Library," Library Journal 19:370-75 (Nov. 1894).

5. "Root, Azariah Smith," National Cyclopedia of American Biography, V.22 (New York: James T. White, 1932), p.112-13.

6. Hendrik Edelman and G. Marvin Tatum, Jr., "The Development of Collections in American University Libraries," College \& Research Libraries 37:223 (May 1976).

7. Richard Rubin, "Azariah Smith Root and Library Instruction at Oberlin College," Journal of Library History, Philosophy and Comparative Librarianship 12:250-61 (Summer 1977).

8. Edwin H. Woodruff, "University Libraries and Seminary Methods of Instruction," $\mathrm{Li}$ brary Journal 11:219-24 (Sept. 1886).

9. William Z. Nasri, "Education in Library and Information Science," Encyclopedia of Library and Information Science, V.7 (New York: Dekker, 1972), p.418.

10. John Mark Tucker, Articles on Library Instruction in Colleges and Universities, 1876-1932, University of Illinois Graduate School of Library Science Occasional Papers, no.143 (Feb. 1980), ED 187330.

11. Samuel Rothstein, The Development of Refer- ence Services through Academic Traditions, Public Library Practice and Special Librarianship (Chicago: Association of Colleges and Reference Libraries, June 1955), gives a general history of the early development of reference service.

12. Charles B. Shaw, "Bibliographic Instruction for Students," Library Journal 53:300-301 (April 1, 1928).

13. Louis Shores, "The Library Arts College: A Possibility in 1954?" School and Society 4:110-14 (Jan. 26, 1935), reprinted from an address delivered in 1934 .

14. Harvie Branscomb, Teaching with Books: A Study of College Libraries (Chicago: Association of American Colleges and American Library Assn., 1940).

15. Jesse Shera, "The Role of the College Librarian-A Reappraisal," in The Role of the College Library-A Reappraisal in LibraryInstructional Integration at the College Level, Report of the 40th Conference of Eastern College Librarians (Chicago: Association of College and Reference Librarians, 1956), p.10.

16. Patricia Knapp, The Monteith College Library Experiment (New York: Scarecrow, 1966).

17. Rothstein, Development of Reference Services, p. 22 .

18. Ben-David, American Higher Education, p.93. 